\title{
Morphological and biomolecular evidence for tuberculosis in 8th century AD skeletons from Bélmegyer-Csömöki domb, Hungary
}

\author{
Erika Molnár ${ }^{\text {a, }}{ }^{\text {, }}$, Helen D. Donoghue ${ }^{b}$, Oona Y.-C. Lee ${ }^{c}$, Houdini H.T. Wu ${ }^{c}$, \\ Gurdyal S. Besra ${ }^{\mathrm{c}}$, David E. Minnikin ${ }^{\mathrm{c}}$, Ian D. Bull ${ }^{\mathrm{d}}$, Gareth Llewellyn ${ }^{\mathrm{e}}$, \\ Christopher M. Williams ${ }^{\mathrm{e}}$, Olga Spekker ${ }^{\mathrm{a}}$, György Pálfi ${ }^{\mathrm{a}}$ \\ a Department of Biological Anthropology, University of Szeged, Szeged, Hungary \\ ${ }^{\mathrm{b}}$ Centre for Clinical Microbiology and Centre for the History of Medicine, University College London, London, UK \\ ${ }^{c}$ Institute of Microbiology and Infection, School of Biosciences, University of Birmingham, Edgbaston, Birmingham, UK \\ ${ }^{\mathrm{d}}$ Organic Geochemistry Unit, School of Chemistry, University of Bristol, Bristol, UK \\ e National Mass Spectrometry Service Centre, School of Medicine, Grove Building, Swansea University, Swansea, UK
}

Keywords:

Ancient DNA

Lipid biomarkers

Mycobacterium tuberculosis complex

Palaeopathology

PCR

\begin{abstract}
S U M M A R Y
Macromorphological analysis of skeletons, from 20 selected graves of the 8th century AD BélmegyerCsömöki domb, revealed 19 cases of possible skeletal tuberculosis. Biomolecular analyses provided general support for such diagnoses, including the individual without pathology, but the data did not show coherent consistency over the range of biomarkers examined. Amplification of ancient DNA fragments found evidence for the Mycobacterium tuberculosis complex DNA only in five graves. In contrast, varying degrees of lipid biomarker presence were recorded in all except two of the skeletons, though most lipid components appeared to be somewhat degraded. Mycobacterial mycolic acid biomarkers were absent in five cases, but the weak, possibly degraded profiles for the remainder were smaller and inconclusive for either tuberculosis or leprosy. The most positive lipid biomarker evidence for tuberculosis was provided by mycolipenic acid, with 13 clear cases, supported by five distinct possible cases. Combinations of mycocerosic acids were present in all but three graves, but in one case a tuberculosis-leprosy co-infection was indicated. In two specimens with pathology, no lipid biomarker evidence was recorded, but one of these specimens provided $M$. tuberculosis complex DNA fragments.
\end{abstract}

(C) 2015 Elsevier Ltd. All rights reserved.

\section{Introduction}

The macromorphological diagnosis of skeletal tuberculosis (TB) in human remains is based upon the detection of secondary skeletal lesions [1]. The most common representation of skeletal TB is spondylitis tuberculosa, which affects the vertebral column. After vertebral involvement, the second most frequent alteration in TB is arthritis of the large, weight-bearing joints [2]. Initially, the diagnosis of TB in osteoarchaeological samples focused only on these

\footnotetext{
* Corresponding author. H-6724, Szeged, Közép fasor 52. Tel./fax: +36 62544 314.

E-mail addresses: balinte@bio.u-szeged.hu (E. Molnár), h.donoghue@ucl.ac.uk (H.D. Donoghue), o.y.lee@bham.ac.uk (O.Y.-C. Lee), h.wu.2@bham.ac.uk (H.H.T. Wu), g.besra@bham.ac.uk (G.S. Besra), d.e.minnikin@bham.ac.uk (D.E. Minnikin), ian.d.bull@bristol.ac.uk (I.D. Bull), g.llewellyn@swansea.ac.uk (G. Llewellyn), christopher.matthew.williams@swansea.ac.uk (C.M. Williams), olga.spekker@gmail.com (O. Spekker), palfigy@bio.u-szeged.hu (G. Pálfi).
}

classical TB lesions, representing a fairly developed stage of tuberculosis. However, TB may have affected many individuals without classical pathological changes, thus patients died in an earlier stage of tuberculosis long before these symptoms could have developed. Clearly, this early-stage TB is not recognizable on the basis of classical TB alterations, so if we consider only individuals with visible TB-related lesions, it is likely this will significantly underestimate the prevalence of tuberculosis in the examined historical populations [1,3].

Because of the problems of tuberculosis diagnostics, the importance of establishing diagnostic criteria for early-stage TB became recognized in the late 20th century. A number of studies mainly based on the examination of skeletal collections with known causes of death - have focused on searching for atypical or early-stage lesions in connection with tuberculosis infection. These investigations enabled the recognition of three types of atypical or early-stage TB alterations: rib lesions, superficial vertebral changes including hypervascularisation, and endocranial alterations [3-7]. 
Positive correlations between tuberculosis and stress indicators, such as long bone periostitis, cribra orbitalia and cribra cranii, were also recognized $[7,8]$. Since the 1990 s, the identification of skeletal tuberculosis in ancient human remains has been facilitated by the confirmation of atypical or early-stage TB lesions by new biomolecular methods based on mycobacterial ancient DNA (aDNA) and lipid biomarker analyses [1,9-12].

In 1990, the first paleopathological analyses of the 8th century $\mathrm{AD}$ series Bélmegyer-Csömöki domb were essentially based on macromorphological and radiological examinations, biomolecular methods were used only in a few cases. From a macromorphological point of view, those investigations only considered classical TB alterations [9,13-15]. An advanced-age female skeleton from the grave No. 65 showed severe osteolytic lesions of the anterior portion of the thoracic and lumbar vertebral bodies, causing an unequal collapse, which led to angular kyphosis (Suppl. Fig. S1 a-b) [14]. Mycobacterial DNA targets IS6110 and the 65-kDa antigen gene, of the Mycobacterium tuberculosis complex (MTBC), were found in samples from this specimen [9]. In another case, of a mature male individual (grave No. 90), the pathological remodelling and fusion of the lumbosacral region and the irregular ante-mortem erosion on the ventral surface of the sacrum, support the diagnosis of a lumbo-sacral tuberculous involvement with cold abscess. In addition, the severe destruction both of the left hip bone and proximal femur is suggestive of tuberculous arthritis or coxitis tuberculosa (Suppl. Fig. S1 c-d) [15]. The diagnosis of skeletal TB was confirmed by biomolecular results, the identification of the DNA-fragment (65-kDa antigen gene) of the MTBC was successful [9]. In a further case, the complete ankylosis of the right knee indicated gonitis tuberculosa of an elderly male individual from grave No. 215 [13].

Marcsik and co-workers published two further classical TB cases in 2007 [16]. A young female skeleton from grave No. 38 exhibited signs of probable tuberculous arthritis (coxitis tuberculosa) of the right hip joint. Skeletal remains of an adult male individual (grave No. 189) presented complete ankylosis of the 9th and 10th thoracic vertebrae and fusion of the 1st and 2nd and the 3rd and 4th lumbar vertebrae. In addition, new bone formation and osteophytes were found on the ventral surfaces of all lumbar vertebral bodies. These alterations suggest the diagnosis of spondylitis tuberculosa [16].

The above mentioned former investigations of the series from the Bélmegyer-Csömöki domb have provided interesting paleopathological cases of skeletal tuberculosis. However, the complete skeletal material has never been analysed systematically for both classical and early-stage TB lesions, and biomolecular analyses had been undertaken only in a few cases. The recent development of diagnostic criteria in the field of paleopathology of TB and biomolecular methods for detection of the MTBC encouraged us to perform a re-examination of the series from 2009. The aim of this study is to summarize the results of this re-examination.

\section{Material and methods}

\subsection{Archaeological background}

The skeletal material for this study derives from the archaeological site of the Bélmegyer-Csömöki domb, rising about three kilometres south-east of the village Bélmegyer, in South-Eastern Hungary. During a long-running excavation (1985-1989), skeletal remains of 240 individuals were unearthed. On the basis of the grave goods found in the completely excavated cemetery, it was used for burials between 670 and $800 \mathrm{AD}$ during the late Avar Period [17,18].

Our research strategy was to combine different diagnostic methods in order to get independent verification using different biomarkers. First we conducted the morphological analysis of the skeletal series. Next, bone samples were taken from the skeletal remains of the suspected TB cases. Small pieces from the same rib were selected and sent to separate centres for the aDNA and lipid biomarker analyses.

\subsection{Macromorphological analysis}

The paleopathological examination of the mostly wellpreserved skeletal remains of the 240 individuals (95 males, 72 females, 73 undeterminable) was carried out in the Department of Biological Anthropology, University of Szeged, Hungary. These investigations were performed using macromorphological methods, focussing on previously detailed classical [2] and atypical TB alterations [3-7].

\subsection{Mycobacterial aDNA analysis}

\subsubsection{Mycobacterial DNA extraction}

Possible cases of skeletal TB, defined according to skeletal morphological alterations, were examined for the presence of aDNA from the M. tuberculosis complex (MTBC). Recommended protocols for aDNA work were followed [19] with separate rooms and equipment for different stages of the process. Well-established methods were employed for aDNA extraction and amplification [20-27] as detailed in Donoghue et al. in this volume [28] and in Supplementary data. The approach used was of a slow but thorough period of sample disruption, one aliquot treated with $\mathrm{N}$-phenacylthiozolium bromide (PTB), to cleave any covalent cross-links thus facilitating DNA strand separation and amplification [21]. Subsequently, samples were treated with guanidium thiocyanate, followed by sample and bacterial cell disruption, using boiling and snap-freezing in liquid nitrogen. All fractions of the sample were used in the extraction. DNA was captured with silica and the pellets washed and dried [28]. Silica supernates from PTB-negative samples were also processed by removal of protein followed by DNA precipitation with isopropanol $\left(-20^{\circ} \mathrm{C}\right)$ [28]. Dried samples were re-hydrated with elution buffer and used immediately or stored at $-20^{\circ} \mathrm{C}$. Negative extraction controls were processed in parallel with the test samples.

\subsubsection{DNA amplification and detection}

Two specific regions of the M. tuberculosis complex were targeted - the repetitive elements IS6110 (1-25 copies/cell) and IS1081 ( 6 copies/cell). The IS6110 primers used for conventional PCR had a target region of $123 \mathrm{bp}$ [22] and the IS1081 primers produce an amplicon of 113 bp [23]. Later, specific M. tuberculosis primers and a fluorescent probe were used [24] to enable shorter DNA fragments to be detected in a real-time PCR reaction (Supplementary data).

\subsubsection{The PCR conditions}

The PCR mix included $2 \mathrm{mM}$ bovine serum albumin to reduce PCR inhibition [25] and $2.0 \mathrm{mM} \mathrm{MgCl}_{2}$. PCR assays were initially run at an annealing temperature of $58{ }^{\circ} \mathrm{C}$ and amplified DNA was examined by agarose gel electrophoresis [26]. Subsequently, amplification was performed in a final volume of $25 \mu \mathrm{l}$ using a RotorGene $^{\odot} 3000$ (Qiagen) real-time platform [27] to enable the detection of DNA using SYBR Green and melt analysis or specific primers with fluorescent probe. Annealing was at $60^{\circ} \mathrm{C}$. A hot-start Taq polymerase was used to minimize non-specific primer and template binding. Negative DNA extraction and PCR controls were processed alongside the test samples. 
Table 1

Data for material investigated from Bélmegyer-Csömöki domb.

\begin{tabular}{|c|c|c|c|c|c|c|c|c|c|c|c|c|}
\hline \multicolumn{13}{|c|}{ Classical TB cases } \\
\hline \multirow[t]{2}{*}{ Gr no } & \multirow[t]{2}{*}{ Sex } & \multirow[t]{2}{*}{ Age at death } & & \multicolumn{3}{|c|}{ Macromorphology } & \multirow[t]{2}{*}{ aDNA } & & \multicolumn{4}{|c|}{ Lipid biomarkers } \\
\hline & & & & ST & $\mathrm{CT}$ & GT & & & MA & & ML & MC \\
\hline 38 & $\mathrm{~F}$ & $16-18$ & & - & & - & - & & + & & $+?$ & + ? \\
\hline 65 & $\mathrm{~F}$ & Maturus & & + & - & - & - & & $+?$ & & + & + \\
\hline 90 & M & $57-62$ & & + & + & - & - & & + & & + & + ? \\
\hline 189 & $\mathrm{M}$ & $25-28$ & & + & - & - & + & & + & & + & + ? \\
\hline 215 & $\mathrm{~F}$ & $55-60$ & & - & - & + & - & & $+?$ & & + & + \\
\hline \multicolumn{13}{|c|}{ Atypical (early-stage) TB cases } \\
\hline \multirow[t]{2}{*}{ Gr no } & \multirow[t]{2}{*}{ Sex } & \multirow[t]{2}{*}{ Age at death } & \multicolumn{5}{|c|}{ Macromorphology } & \multirow[t]{2}{*}{ aDNA } & & \multicolumn{3}{|c|}{ Lipid biomarkers } \\
\hline & & & SVC & $\mathrm{RP}$ & EL & LBP & $\mathrm{CO}$ & & & MA & ML & $\mathrm{MC}$ \\
\hline 12 & M & $33-39$ & - & +++ & - & + & - & + & & $+?$ & ++ & $+?$ \\
\hline 17 & $\mathrm{M}$ & $22-25$ & + & + & + & + & + & + & & $+?$ & ++ & $+?$ \\
\hline 22 & undet. & $16-18$ & + & - & + & - & - & - & & + & ++ & + \\
\hline 33 & M & $40-45$ & + & - & + & + & + & + & & - & - & - \\
\hline 48 & M & $55-60$ & + & + & - & $+(\mathrm{DP})$ & - & + & & + & + & + \\
\hline 66 & $F$ & $61-67$ & + & + & - & - & - & + & & - & + & $+?$ \\
\hline 86 & M & $59-64$ & - & - & - & - & - & - & & + & ++ & + \\
\hline 88 & $\mathrm{~F}$ & $40-45$ & - & +++ & - & - & - & + & & + & + & +++ \\
\hline 92 & M & $20-25$ & + & +++ & - & + & - & + & & + & $+?$ & $+?$ \\
\hline 116 & $\mathrm{~F}$ & $25-30$ & - & +++ & + & $+++(\mathrm{DP})$ & - & - & & + & $+?$ & $+?$ \\
\hline 134 & $\mathrm{~F}$ & $16-18$ & + & - & - & - & + & - & & ++ & + & + \\
\hline 154 & M & $20-24$ & + & - & - & - & + & + & & - & $+?$ & - \\
\hline 188 & undet. & 7 & + & - & - & - & - & - & & - & ++ & + \\
\hline 212 & M & $18-20$ & + & + & - & - & - & - & & - & - & - \\
\hline 233 & $\mathrm{~F}$ & $23-25$ & - & - & + & - & - & - & & + & $+?$ & $+?$ \\
\hline
\end{tabular}

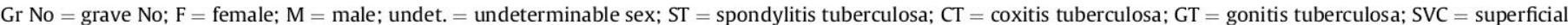

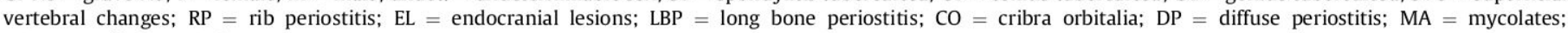
$\mathrm{ML}=$ mycolipenate; $\mathrm{MC}=$ mycocerosates.

\subsection{Lipid biomarker analysis}

Details of the methods and analysis are given in the Supplementary data. Specimens were hydrolysed by heating with $30 \%$ potassium hydroxide in methanol $(2 \mathrm{ml})$ and toluene $(1 \mathrm{ml})$ at $100{ }^{\circ} \mathrm{C}$ overnight $[11,29]$. In parallel, standard biomass of $M$. tuberculosis and M. leprae was processed. Long-chain compounds were extracted as described previously [29] and the extract was treated with pentafluorobenzyl bromide, under phase-transfer conditions [11,29] to convert acidic components into pentafluorobenzyl (PFB) esters. Subsequent separation on an Alltech 209250 (500 mg) normal phase silica gel cartridge gave fractions containing non-hydroxylated fatty acid PFB esters, mycolic acid (MA) PFB esters and free phthiocerols [11,29]. The MA PFB esters reacted with pyrenebutyric acid $\mathrm{fi}(\mathrm{PBA})$ to produce PBA-PFB MA derivatives, which were purified on an Alltech $205250(500 \mathrm{mg}) C_{18}$ reverse phase cartridge $[11,29]$. The PBA-PFB mycolates were analysed by reverse phase HPLC, as described previously $[11,29]$. The non-hydroxylated PFB ester fractions were refined on an Alltech 205250 (500 mg) reverse phase silica gel cartridge, using a watermethanol/methanol/methanol-toluene elution sequence [29]. A fraction enriched in mycocerosic acid and other longer chain (>C20) PFB esters was eluted by $100 \%$ methanol with the more usual $C_{12}$ to $C_{20}$ esters eluting in the earlier water/methanol fractions. The fractions containing possible mycocerosates, were analysed by negative ion chemical ionization gas chromatography mass spectrometry (NICI-GCMS), as previously described [29].

\section{Results}

\subsection{Macromorphological analysis}

During the macromorphological analysis of the skeletal material of the Bélmegyer-Csömöki domb, 19 cases of probable skeletal tuberculosis were detected. Classical TB changes were observed in the five cases detailed above in the Introduction (Suppl. Fig. S1 a-d; Table 1), while atypical or early-stage TB lesions were observed in a further 14 cases (Suppl. Fig. S2 a-c; Table 1). It is clear, therefore, that these atypical or early TB changes occurred significantly more often than the classical alterations. Only grave No. 86 showed no macromorphological evidence of tuberculosis (Table 1).

The most frequent lesions were periosteal reactions on the visceral rib surfaces and abnormal vertebral vascularisation. Ten cases of superficial vertebral changes were detected (Table 1). With the exception of three specimens (two mature males and one elderly female), the affected individuals belong to younger age groups: one Infans II, three juveniles and three young adult males. Eight individuals exhibited hypervascularisation of the anterior aspect of vertebral bodies, while lytic vertebral lesions were revealed in only two cases.

As for rib changes, eight individuals (one juvenile, four adults, two mature and one elderly) showed signs of periosteal appositions on the visceral costal surfaces (Table 1). In the majority of the cases, rib periostitis showed a woven-remodelled character, indicating a less active process generating these pathological changes. In two other cases (grave No. 17 and grave No. 212) it was noticed that the visceral surfaces of ribs had a roughened texture.

Endocranial alterations were revealed in five individuals only (Table 1). Except for a mature male specimen (grave No. 33), the affected individuals represent younger age groups: one juvenile and three young adults (one male and two females). Concerning lesion morphology, abnormal blood vessel impressions on the internal surface of the skull were observed in three of the five cases, though the endocranial lamina of grave No. 22 exhibited small granular impressions similar to those described by Schultz [5] and in the skeleton of a young adult female individual (grave No. 233) serpens endocrania symmetrica (SES) was identified. 


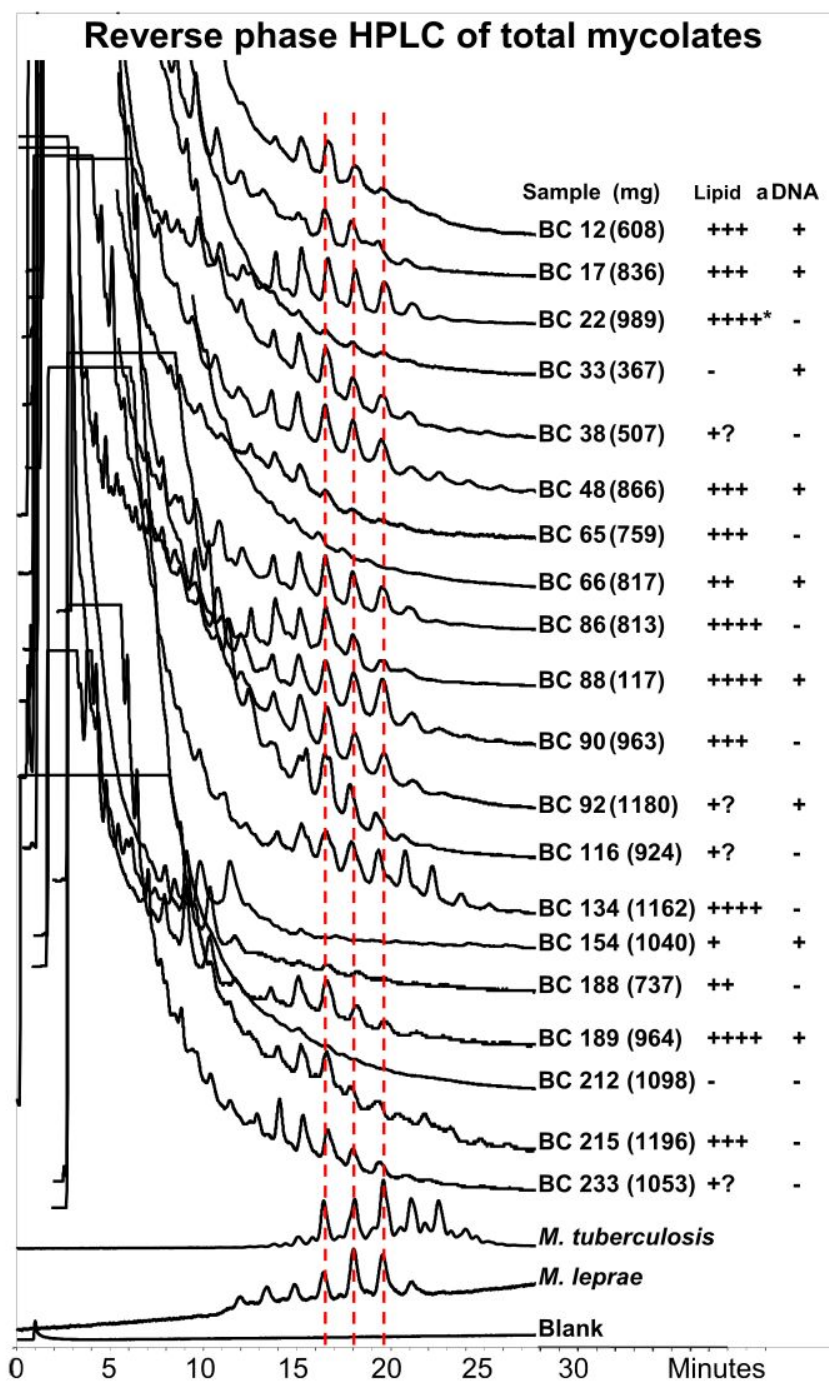

Figure 1. Reverse phase fluorescence HPLC of total mycolates. The grave numbers are accompanied (in brackets) by the amount of sample analysed (mg). The "Lipid" column indicates the diagnostic power of mycolate (MA), mycolipenate (ML) and mycocerosate (MC) lipid biomarkers: ++++ (group 1), clear evidence of MA, ML and MC; +++ (group 2), clear ML signal with less strong MA and MC; ++ (group 3), good ML, weak MC and no MA; + (group 4), only a clear weak ML peak; +? (group 5), weak inconclusive ML and MC with some MA support; - (group 6), no evidence of mycobacterial lipids; $++++^{*}$, strong $M$. tuberculosis lipid signals with additional MC indicating $M$. leprae. The "aDNA" list records the presence of amplified DNA fragments.

With the exception of two cases (grave No. 88 and grave No. 188), an association of different alterations could be detected. Atypical or early-stage TB changes were accompanied by stress factors in a number of cases: cribra orbitalia (mainly the porotic form) was observed in seven cases, while long bone periostitis occurred in six cases (Table 1). Long bone periostitis appeared mostly on femora and tibiae, but in three cases the long bones of the upper extremities were also affected.

\subsection{Biomolecular analyses}

The aDNA amplification studies gave positive results for nine of the 20 graves investigated, but for only one of the four "classical TB cases" (Table 1). Full data of the aDNA analysis are provided in Supplementary data. Total mycolic acid (MA) profiles are recorded in Figure 1 that also includes a summary of the overall lipid biomarker and aDNA results. All the MA profiles were too weak to allow further diagnostic analyses, by sequential normal and reverse phase HPLC [11,29]. Material from five graves (Nos. 33, 66, 154, 188, 212) yielded no MAs. Figure 2 shows three representative profiles of mycolipenic (ML) and mycocerosic (MC) acids; full data are provided in Supplementary Figures S3, S4 and S5.

The results of the lipid biomarker analyses could be placed into 6 groups (Table 1, Figs. S3-5). Group 1 (grave Nos. 22, 86, 88, 134) had clear evidence of all three MA, ML and MC lipid biomarker classes; grave No. 22, however, also included $C_{33}$ and $C_{34}$ mycocerosates, indicative of leprosy. The major Group 2 (grave Nos. 12, $17,48,65,90,189,215)$ was characterised by the presence of a clear signal for mycolipenate (ML), with less convincing evidence for the other MA and MC classes. Group 3 (grave Nos. 66, 188) had two representatives with good ML, weak MCs, but no MA; a single member of Group 4 (grave No.154) had only a poor ML signal. Four representatives in Group 5 (grave Nos. 38, 92, 116, 233) provided weak inconclusive evidence for ML and MC biomarkers. Final Group 6 (grave Nos. 33, 212) lacked any evidence of mycobacterial lipid biomarkers. A close correlation with the aDNA data was not observed. Only one (grave No. 88) of four in the best Group 1 lipid class gave amplified DNA. Correlation was better for the Group 2 lipid class with four of seven having aDNA. In the less strong or negative lipid Groups 3-6, only one grave in each group had a positive aDNA result.

\section{Discussion and conclusions}

In 19 out of the 20 skeletons from Bélmegyer-Csömöki domb a range of macromorphological changes, indicative of tuberculosis, were observed. Only nine of the 20 graves yielded $M$. tuberculosis aDNA on amplification. Lipid biomarker evidence for M. tuberculosis was discerned in all but two of the specimens, but the strength and conclusiveness of the lipid signals could be allocated to five levels (Groups 1-5) (Figure 2). Taken by themselves, the weak total mycolic acid profiles (Figure 2) cannot be regarded as positive evidence for ancient tuberculosis. The constituents of the profiles are significantly smaller than those of standard M. tuberculosis, suggesting either considerable degradation or the presence of environmental mycobacteria. The former alternative is favoured, as the two specimens (grave Nos. 33, 212) that lacked any evidence of mycolipenate (ML) and mycocerosate (MC) biomarkers (Table 1), showed no evidence of any mycolates (Figure 2). Given that assumption, the MA profiles provide background support for mycobacterial infection.

The most positive evidence for the presence of tuberculosis resides in the MLs, which were found to be usually, as strong as, or stronger than the MCs, an exception being grave No. 88 with an excellent MC profile. Indeed in grave No. 154 the only lipid biomarker evidence is a very weak ML signal; this is probably genuine as aDNA was amplified from this sample.

Of five classical tuberculosis cases (Table 1) with skeletal alterations characteristic for advanced stage TB, one only (grave No.189) was positive for MTBC DNA with clear lipid biomarker support (Figure 2; Table 1). Four of the diagnosed classical TB cases were DNA negative. However, in three of these negative cases (grave Nos. $65,90,215$ ) the diagnosis of skeletal tuberculosis was confirmed by lipid biomarker analysis with quite strong evidence (Figure 2). For grave No. 38, lipid biomarker data were weak.

For cases, showing atypical or early-stage TB lesions (Table 1), many of the biomarker results were inconsistent. The best lipid profiles (Group. 1) were recorded for grave Nos. 22, 86, 88 and 134, but only the very fragmented material from grave No. 88 was supported by aDNA. Interestingly, grave No. 22 appeared to be a coinfection with tuberculosis and leprosy, the former being confirmed with a strong mycolipenate peak and the latter by $C_{33}$ 


\section{A. BC 88}

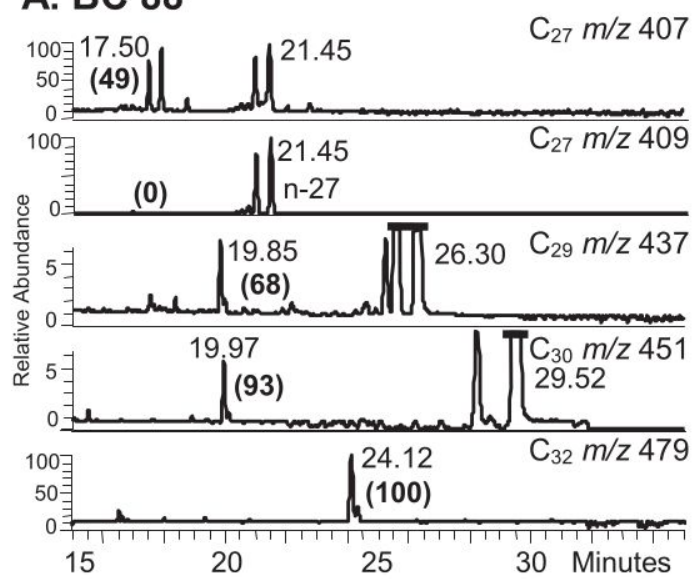

C. BC 134

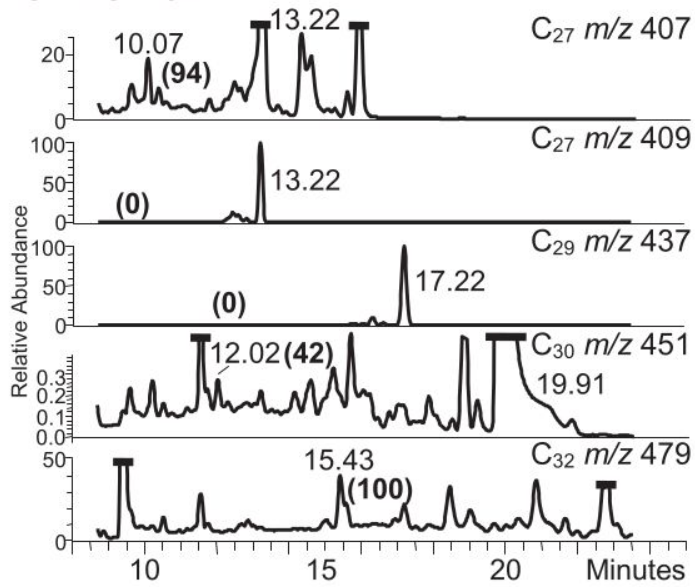

E. BC 22

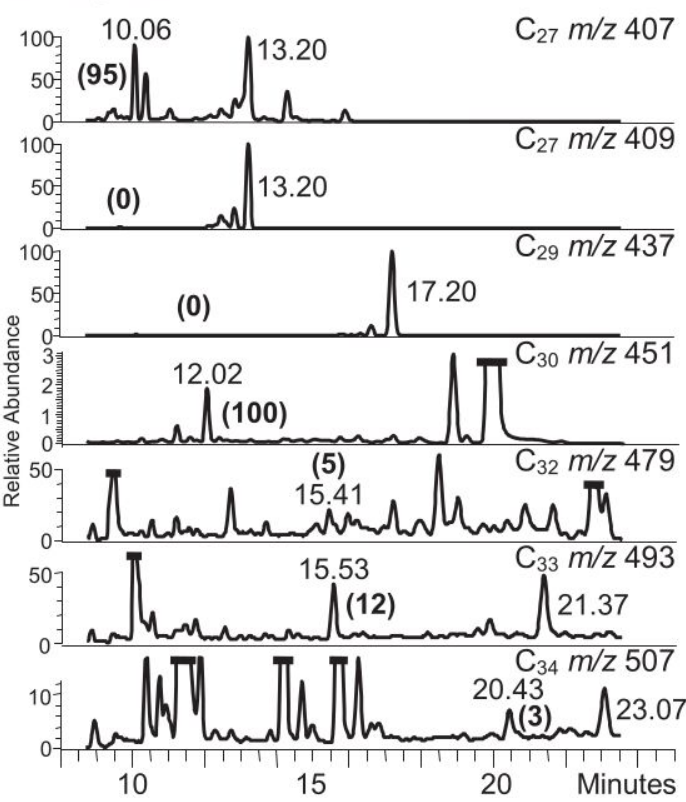

\section{B. M. tuberculosis PN (Bristol)}

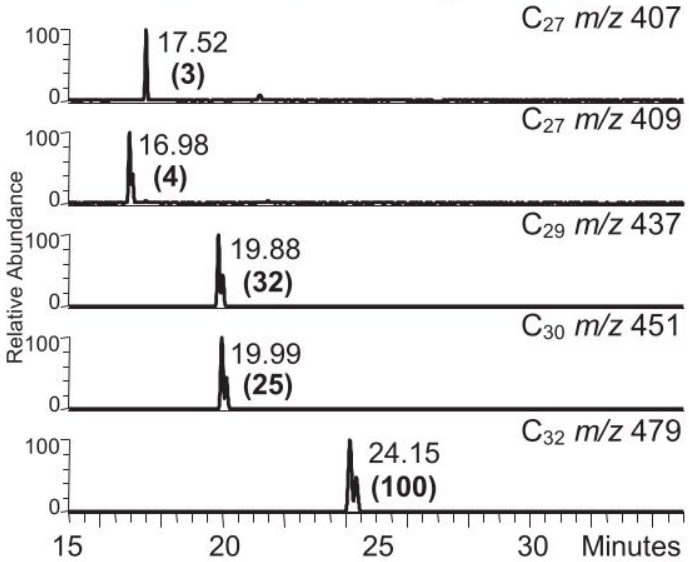

\section{M. tuberculosis Strain C (Swansea)}

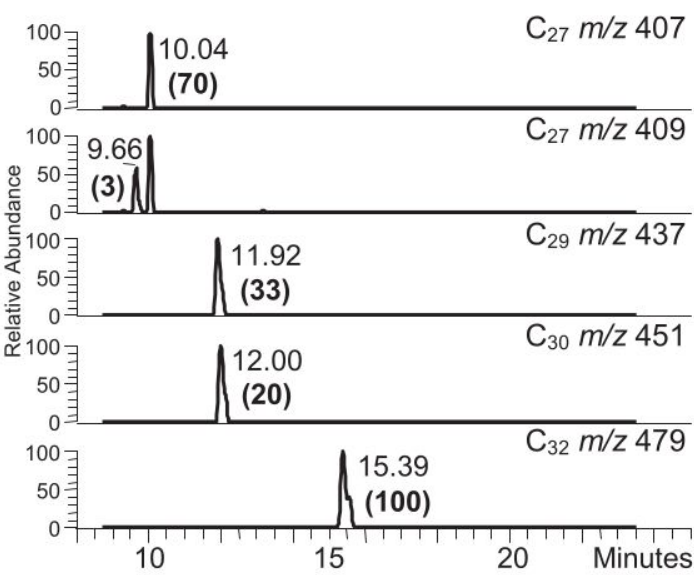

\section{F. M. leprae (Swansea)}

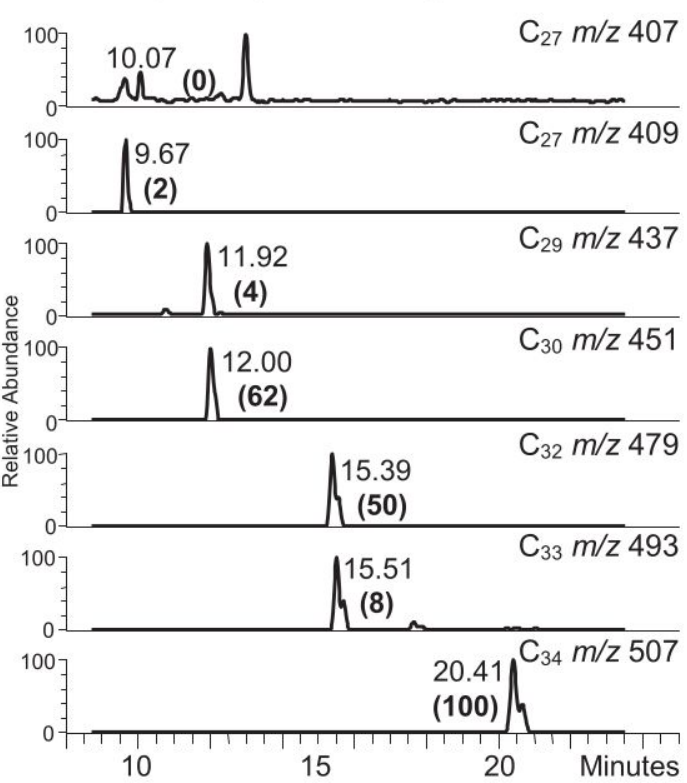

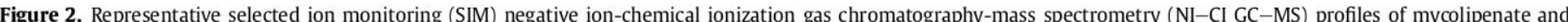

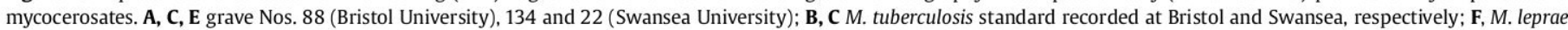

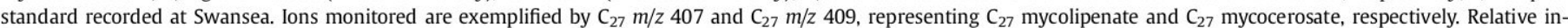
tensities (bold in brackets) are shown normalized to the major component (100). 
and $C_{34}$ mycocerosates (Figure 2). The next Group 2 lipid biomarker level, with clear ML backed up by MCs in seven graves (Nos. 12, 17, $48,65,90,189,215$ ) was supported by aDNA in three atypical cases (grave Nos. 12, 17, 48) in addition to the classical case in grave No. 189 (Table 1). Only one (grave No. 66) of the two Group 3 biomarker level specimens had aDNA support, but both graves (Nos. 66, 188) had good ML backed up by weak but clear MCs. Dropping down to the single lipid biomarker Group 4 representative (grave No. 154), as mentioned above, aDNA amplification was supported by a weak but clear ML. The four graves (Nos. 38, 92, 116, 233) assigned to lipid Group 5 had only minimal ML and MC evidence but aDNA was obtained from No. 92. Although grave No. 33 was MTBC DNA positive, negative lipid profiles were recorded. A juvenile male (grave No. 212.) was the only specimen showing atypical or early-stage TB lesions, where the biomolecular analyses gave negative results for the presence of both MTBC DNA and lipid biomarkers. The presence of mycolic acid biomarkers in material from grave No. 65 was previously suggested [30] but the scientific basis for such a diagnosis has been dismissed [31].

Morphological assessment, detection of ancient DNA and demonstration of $M$. tuberculosis complex cell wall lipid markers proves there was widespread TB infection in this 8th century population. A variety of lesions at different stages of development were observed. The biomolecular studies confirmed the presence of tuberculosis and lipid analysis also indicated a TB/leprosy coinfection. Our study highlights the difficulties of demonstrating TB in these individuals from over 1300 years ago and the importance of using different methods is very clear. The relative success of lipid biomarkers compared with aDNA is probably due to their greater stability over time. This underlines the complementarity of morphological, aDNA and lipid biomarkers analyses in the diagnosis of ancient TB infections.

Funding: The Leverhulme Trust Project Grant F/00 094/BL (OY-CL, DEM, GSB). GSB was supported by a Personal Research Chair from Mr. James Bardrick and the UK Medical Research Council. The UK Engineering and Physical Sciences Research Council (EPSRC) funded the UK National Mass Spectrometry Facility at Swansea University (GL, CMW). The UK National Environmental Research Council (NERC) provided funding for the mass spectrometry facilities at Bristol (Contract no. R8/H12/15; www.lsmsf.co.uk) (IDB). The Hungarian Scientific Research Fund OTKA (OTKA Grant No. K78555 and NN 78696) provided funding for the macromorphological studies.

\section{Competing interests: None declared.}

\section{Ethical approval: Not required.}

\section{Author contributions}

EM and GP conceived the study and with OS performed the macromorphological analysis. HD performed the aDNA studies. DM and GB conceived the lipid work, which was performed by OL, HW, IB, GL and CW. The lipid data were analysed by DM, GB, OL and HW. EM, DM and HD wrote the manuscript and all authors approved the final version.

\section{Appendix A. Supplementary data}

Supplementary data related to this article can be found at http:// dx.doi.org/10.1016/j.tube.2015.02.032

\section{References}

[1] Pálfi Gy, Bereczki Zs, Ortner DJ, Dutour O. Juvenile cases of skeletal tuberculosis from the terry anatomical collection (Smithsonian Institution, Washington, D.C., USA). Acta Biol Szeged 2012;56:1-12.

[2] Ortner DJ. Identification of paleopathological conditions in human skeletal remains. San Diego: Academic Press; 2003.

[3] Dutour O. Archaeology of human pathogens: palaeopathological appraisal of palaeoepidemiology. In: Raoult D, Drancourt M, editors. Paleomicrobiology: past human infections. Berlin, Heidelberg: Springer-Verlag GmbH; 2008. p. $125-44$.

[4] Baker BJ. Early manifestations of tuberculosis in the skeleton. In: Pálfi Gy, Dutour O, Deák J, Hutás I, editors. Tuberculosis: past and present. Szeged \& Budapest: TB Foundation \& Golden Book Publisher; 1999. p. 301-7.

[5] Schultz M. Paleohistopathology of bone: a new approach to the study of ancient diseases. Yearb Phys Anthropol 2001;44:106-47.

[6] Hershkovitz I, Greenwald CM, Latimer B, Jellema LM, Wish-Baratz S, Eshed V Dutour O, Rothschild BM. Serpens endocrania symmetrica (SES): a new term and a possible clue for identifying intrathoracic disease in skeletal populations. Am J Phys Anthropol 2002;118:201-16.

[7] Pálfi Gy. Paleoepidemiological reconstruction of tuberculosis with particular attention to Europe. In: Bennike P, Bodzsár E, Susanne C, editors. Biennial books of EAA, vol. 2; 2002. p. 193-210.

[8] Stuart-Macadam PL. Nutritional deficiency diseases: a survey of scurvy, rickets and iron deficiency anemia. In: Isçan MY, Kennedy KAR, editors. Reconstruction of life from the skeleton. New York: Alan R. Liss Publisher; 1989 p. $201-22$.

[9] Haas C], Zink A, Molnár E, Szeimies U, Reischl U, Marcsik A, Ardagna Y, Dutour O, Pálfi Gy, Nerlich AG. Molecular evidence for different stages of tuberculosis in ancient bone samples from Hungary. Am J Phys Anthropol 2000;113:293-304.

[10] Zink AR, Molnár E, Motamedi N, Pálfi Gy, Marcsik A, Nerlich AG, Molecular history of tuberculosis from ancient mummies and skeletons. Int J Osteoarchaeol 2007; 17:380-91.

[11] Hershkovitz I, Donoghue HD, Minnikin DE, Besra GS, Lee OY-C, Gernaey AM, Galili E, Eshed V, Greenblatt CL, Lemma E, Bar-Gal GK, Spigelman M. Detection and molecular characterization of 9000-year-old Mycobacterium tuberculosis from a neolithic settlement in the Eastern Mediterranean. PLoS One 2008;3: e3426.

[12] Pósa A, Maixner F, Lovász G, Molnár E, Bereczki Zs, Perrin P, Zink AR, Pálfi Gy Revision of tuberculous lesions in the Bácsalmás-Óalmás series - preliminary morphological and biomolecular studies. Anthropologischer Anzeiger 2013;70:83-100. http://dx.doi.org/10.1127/0003-5548/2012/0260.

[13] Pálfi Gy, Csernus Z. Arthrite infectieuse ankylosante dans une série du VIIle siècle en Hongrie. Paléobios 1990;6:37-41.

[14] Pálfi Gy. The osteoarchaeological evidence of vertebral tuberculosis in the 8th century. Acta Biol Szeged 1991;37:101-5.

[15] Pálfi Gy, Marcsik A, Kovács J. Lumbosacral and hip tuberculosis in a migration period skeleton. J Paleopathol 1992;4:179-84.

[16] Marcsik A, Molnár E, Ösz B. Specifikus fertőző megbetegedések csontelváltozásai történeti népesség körében. Szeged: JatePress; 2007. p. 26-7.

[17] Medgyesi P. Késö avar temetö Bélmegyer-Csömöki dombon (Elözetes jelentés). Spätawarenzeitliches Gräberfeld auf Hügel Bélmegyer-Csömök (Vorbericht). Szeged: A Móra Ferenc Múzeum Évkönyve; 1991. p. 241-56.

[18] Medgyesi P. Bélmegyer. In: Jankovich BD, editor. Magyarország régészeti topográfiája. 10. Békés megye régészeti topográfiája. Budapest: Akadémiai Kiadó; 1998, p. 342-8.

[19] Taylor GM, Mays SA, Huggett JF. Ancient DNA (aDNA) studies of man and microbes: general similarities, specific differences. Int J Osteoarchaeol 2010;20:747-51.

[20] Donoghue HD, Marcsik A, Matheson C, Vernon K, Nuorala E, Molto J Greenblatt C, Spigelman M. Co-infection of Mycobacterium tuberculosis and Mycobacterium leprae in human archaeological samples-a possible explanation for the historical decline of leprosy. Proc R Soc B Biol Sci 2005;272: 389-94.

[21] Poinar HN, Hofreiter M, Spaulding WG, Martin PS, Stankiewicz BA, Bland H, Evershed EP, Possnert G, Pääbo S. Molecular coproscopy: dung and diet of the extinct ground sloth Nothrotheriops shastensis. Science 1998;281:402-6.

[22] Eisenach KD, Cave MD, Bates JH, Crawford JT. Polymerase chain reaction amplification of a repetitive DNA sequence specific for Mycobacterium tuberculosis. J Infect Dis 1990;161:977-81.

[23] Taylor GM, Stewart GR, Cooke M, Chaplin S, Ladva S, Kirkup J, Palmer S, Young DB. Koch's Bacillus - a look at the first isolate of Mycobacterium tuberculosis from a modern perspective. Microbiology 2003;149:3213-20.

[24] Évinger S, Bernert Zs, Fóthi E, Wolff K, Kövári I, Marcsik A, Donoghue HD, O'Grady J, Kiss KK, Hajdu T. New skeletal tuberculosis cases in past populations from Western Hungary (Transdanubia). HOMO - J Comp Hum Biol 2011;62:165-83.

[25] Abu Al-Soud W, Rådström P. Effects of amplification facilitators on diagnostic PCR in the presence of blood, feces and meat. J Clin Microbiol 2000;38: 4463-70.

[26] Hajdu T, Donoghue HD, Bernert Zs, Fóthi E, Kövári I, Marcsik A. A case of spinal tuberculosis from the middle ages in Transylvania (Romania). Spine 2012;37: e1598-1601. 
[27] Taylor GM, Worth DR, Palmer S, Jahans K, Hewinson RG. Rapid detection of Mycobacterium bovis DNA in cattle lymph nodes with visible lesions using PCR. BMC Veterinary Res 2007;3:12-22.

[28] Donoghue HD, Spigelman M, O'Grady J, Szikossy I, Pap I, Lee OY-C, Wu HHT Besra GS, Minnikin DE. Ancient DNA analysis - an established technique in charting the evolution of tuberculosis and leprosy. Tuberculosis 2015;95. http://dx.doi.org/10.1016/j.tube.2015.02.020.

[29] Lee OY-C, Wu HHT, Donoghue HD, Spigelman M, Greenblatt CL, Bull ID, Rothschild BM, Martin LD, Minnikin DE, Besra GS. Mycobacterium tuberculosis complex lipid virulence factors preserved in the 17,000-year-old skeleton of an extinct bison. Bison Antiq PLoS One 2012;7:e41923.
[30] Mark L, Patonai Z, Vaczy A, Lorand T, Marcsik A. High-throughput mass spectrometric analysis of 1400-year-old mycolic acids as biomarkers for ancient tuberculosis infection. J Archaeol Sci 2010;37:302-5.

[31] Minnikin D, Lee OY-C, Wu HHT, Besra G, Donoghue H. Molecular biomarkers for ancient tuberculosis. In: Cardona P-J, editor. Understanding tuberculosis deciphering the secret life of the bacilli. Rijeka, Croatia: InTech Open Access Publisher; 2012. p. 3-36. ISBN-13: 978-953-307-946. Available from: http:// www.intechopen.com/articles/show/title/molecular-biomarkers-for-ancienttuberculosis. 